\title{
㪌 New Disease Reports \\ First report of Erysiphe corylacearum on Corylus avellana and C. colurna in Austria
}

H. Voglmayr ${ }^{1,2 *}$, T. Zankl $^{2}$, I. Krisai-Greilhuber ${ }^{1}$ and T. Kirisits ${ }^{2}$

\begin{abstract}
${ }^{1}$ Department of Botany and Biodiversity Research, University of Vienna, Rennweg 14, 1030 Wien, Austria; ${ }^{2}$ Institute of Forest Entomology, Forest Pathology and Forest Protection, Dept. of Forest and Soil Sciences, University of Natural Resources and Life Sciences Vienna (BOKU), Peter-Jordan-Straße 82, 1190 Vienna, Austria
\end{abstract}

*E-mail: hermann.voglmayr@boku.ac.at

Received: 28 Sep 2020. Published: 07 Nov 2020. Keywords: hazelnut, obligate parasite, powdery mildew

In September 2020, prominent powdery mildew disease symptoms were seen on leaves of Corylus avellana (hazelnut) and C. colurna (Turkish hazelnut) at several localities in eastern and southern Austria (Burgenland, Carinthia, Lower Austria, Styria, Vienna). The symptoms differed from those previously observed (caused by Phyllactinia guttata) by mycelia on the upper leaf surface and by smaller chasmothecia with branched appendices. The disease was observed on Corylus spp. growing in mixed deciduous forests, hedges as well as city gardens and parks.

Disease symptoms started as small spots of white, amphigenous surface mycelium, that radially enlarged to form effuse patches reaching up to 2 $\mathrm{cm}$ in diameter, eventually becoming confluent and then covering the entire leaf surface (Figs. 1-2). Infections on the lower leaf surface caused chlorotic spots on the upside (Fig. 1). Upon severe infection, leaves were distorted (Figs. 1-2). On surface mycelium, ellipsoid to doliiform conidia (27-36 $\times 18-23 \mu \mathrm{m})$ were produced singly on conidiophores (Fig. 3). In addition, dark brown chasmothecia, 70-120 $\mu \mathrm{m}$ in diameter were abundantly produced (Fig. 4), which had up to $15,60-90 \mu \mathrm{m}$ long, stiff, hyaline appendages with repeatedly dichotomously branched tips. They contained 2-6 broadly ellipsoid, mostly (3-)7-8 spored asci of 51-70 $\times$ 38-57 $\mu \mathrm{m}$, with hyaline ascospores 19-28 $\times 13-18 \mu \mathrm{m}$ (Fig. 5). Based on these characters, the powdery mildew was identified as Erysiphe corylacearum (Braun \& Cook, 2012).

To confirm the morphological identification, the ITS-LSU of sample WU 43287 (Lower Austria, Gießhübl, host: Corylus avellana) was sequenced. DNA was extracted from chasmothecia using the innuPREP DNA Micro Kit (Analytik Jena, Germany) according to the manufacturer's instructions, with a lysis time of 16 hours. The ITS-partial LSU was amplified as a single stretch with primers V9G and LR5 and sequenced according to Voglmayr et al. (2019). The obtained sequence was deposited in GenBank (Accession No. MW031866), and representative voucher specimens were deposited in the fungarium of the University of Vienna (WU 43287, WU 43421, WU 43423, WU 43424, WU 43514, WU 43515, WU 43520, WU 43525). A nBLAST analysis revealed $99-100 \%$ identity to sequences of $E$. corylacearum, with $100 \%$ identity to sequences from Azerbaijan (LC270863), Iran (MF668615, MH047243), Japan (MT095104), Switzerland (MN822721-MN822723) and Turkey (KY082910), confirming the species identification.

Native to East Asia and probably North America, E. corylacearum was firs
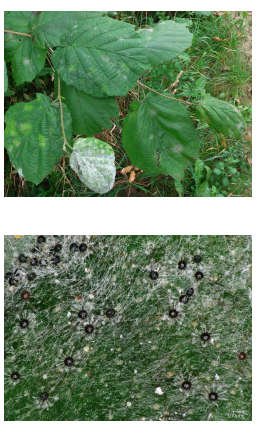

Figure 1

Figure 4 observed in Turkey in 2013 and has since rapidly extended its distribution range to West Asia as well as Eastern and Central Europe (Beenken et al., 2020; Heluta \& Fokshei, 2020). Erysiphe corylacearum has been reported as a severe invasive alien pathogen, causing significant yield losses in hazelnut orchards in Turkey, Iran and Georgia (Arzanlou et al., 2018; Meparishvili et al., 2019).

\section{Acknowledgements}

The authors thank Christian Scheuer for information on a record from Styria.

\section{References}

1. Arzanlou M, Torbati M, Golmohammadi H, 2018. Powdery mildew on hazelnut (Corylus avellana) caused by Erysiphe corylacearum in Iran. Forest Pathology 48, e12450. http://dx.doi.org/10.1111/efp. 12450

2. Beenken L, Brodtbeck T, De Marchi R, 2020. First record of Erysiphe corylacearum on Corylus avellana in Switzerland and in central Europe. New Disease Reports 41, 11. http://dx.doi.org/10.5197/j.2044-0588.2020.041.011

3. Braun U, Cook RTA, 2012. Taxonomic manual of the Erysiphales (powdery mildews), CBS Biodiversity Series. Utrecht, The Netherlands: Centraalbureau voor Schimmelcultures.

4. Heluta VP, Fokshei SI, 2020. New records of an alien fungus Erysiphe corylacearum (Erysiphales, Ascomycota) in Ukraine. Plant \& Fungal Research 3, 11-17. http://dx.doi.org/10.29228/plantfungalres.64

5. Meparishvili G, Gur L, Frenkel O, Gorgiladze L, Meparishvili S, Muradashvili M, Koiava L, Dumbadze R, Reuveni M, Jabnidze R, 2019. First report of powdery mildew caused by Erysiphe corylacearum on hazelnuts in Georgia. Plant Disease 103, 2952. http://dx.doi.org/10.1094/PDIS-05-19-1053-PDN

6. Voglmayr H, Jaklitsch WM, Mohammadi H, Kazemzadeh Chakusary M, 2019. The genus Juglanconis (Diaporthales) on Pterocarya. Mycological Progress 18, 425-437. http://dx.doi.org/10.1007/s11557-018-01464-0



Figure 2

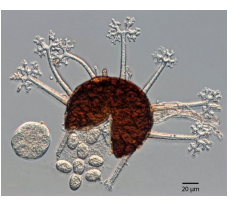

Figure 3



To cite this report: Voglmayr H, ZankI T, Krisai-Greilhuber I, Kirisits T, 2020. First report of Erysiphe corylacearum on Corylus avellana and C. colurna in Austria. New Disease Reports 42, 14. http://dx.doi.org/10.5197/j.2044-0588.2020.042.014

(c) 2020 The Authors

This report was published on-line at www.ndrs.org.uk where high quality versions of the figures can be found. 